\title{
Salivary gland type cancer of the breast
}

INSERM

\section{Source}

INSERM. (1999). Orphanet: an online rare disease and orphan drug data base. Salivary gland type cancer of the breast. ORPHA:213557

Salivary gland type cancer of the breast describes a group of uncommon neoplasms, usually seen in the salivary glands but occurring in the breast, with a variable clinicopathologic spectrum and divided into those with myoepithelial differentiation and those without. This group includes mammary adenoid cystic carcinoma, adenoid cystic carcinoma (see this term), mucoepidermoid carcinoma, acinic cell carcinoma, polymorphous low-grade adenocarcinoma and oncocytic carcinoma. 